\title{
Development of prototype electronic dashboard service performance of LPKA class I Palembang
}

\author{
Hendra Hadiwijaya ${ }^{1)}$, Febrianty ${ }^{2)}$, Rezania Agramanisti Azdy ${ }^{3)^{*}}$ \\ 1)2) PalComTech Polytechnic, ${ }^{3 *}$ STMIK PalComTech, Indonesia \\ ${ }^{1)}$ hendra_hadi@palcomtech.ac.id, ${ }^{2)}$ febrianty@palcomtech.ac.id, ${ }^{3)}$ rezania@palcomtech.ac.id
}

\begin{abstract}
Submitted : Nov 14, 2020 | Accepted : Mar 28, 2021 | Published : Apr 27, 2021
Abstract: LPKA Palembang provides services to the community in the form of coaching in the fields of education, skills training, community guidance, and alleviation, services for Andikpas visits and complaints, remission submission services, assimilation, and other submissions especially to support alleviation programs such as the Conditional Leave (CB) program, Leaving Towards Free $(\mathrm{CMB})$, and Parole $(\mathrm{PB})$. To provide the best convenience and quality in providing services, a system is needed that can not only be used to submit and process service data online, but also can integrate service data so that it can be more easily accessed anytime and anywhere. The system created is an electronic dashboard or e-dashboard that can present data visually so that it is easily understood by readers. This study aims to build a prototype that can provide an overview of the e-dashboard system to be built. From the prototype evaluation, user feedback can be obtained which can be used to build an actual e-dashboard system so that it can reduce deviations from the system being built. The stages in this research are planning, designing, building, and evaluating the prototype. The results of this study are the development of eDashboard prototype that had been tested by $80 \%$ of LPKA Class I Palembang employees. The developed prototype has features that almost meet user needs because the system development is based on a quick analysis of the needs of future e-Dashboard users.
\end{abstract}

Keywords: prototype, e-dashboard, LPKA performance services

\section{INTRODUCTION}

Based on the Regulation of the Minister of Law and Human Rights of the Republic of Indonesia Number 18 of 2015 concerning the Organization and Work Procedure of Special Guidance Institutions for Children, there are 33 LPKAs within the Ministry of Law and Human Rights, with 7 of LPKA Class I, and the rest are LPKA Class II. LPKA Class I Palembang is an LPKA domiciled in Palembang with a Regional Office in South Sumatra Province. LPKA Class I Palembang has a maximum capacity of 500 Correctional Students (Andikpas) with an average number of Andikpas per year is 200 people (Febrianty, Hadiwijaya, and Octafian 2019).

Public services provided by LPKA Class I are in the form of coaching in the fields of education, skills training, community guidance, and alleviation, services for Andikpas visits and complaints, services for submitting remissions, assimilation, and other submissions especially to support alleviation programs such as the Conditional Leave (CB) program, Leaving Towards Free (CMB), and Parole (PB). So far, some of the information and service requests can be accessed through the web http://pkapalembang.kemenkumham.go.id/, and some of the rest are still being submitted and processed conventionally. Web tersebut juga terkadang tidak bisa diakses sehingga perlu sistem pendukung seperti e-dashboard. The weakness of the current system is the difficulty of monitoring and collecting data because the data is scattered and stored in various forms in different places. To overcome these weaknesses, a computer-based system can be created that can integrate all existing service data so that it can be accessed easily and quickly whenever needed. The system created is an electronic dashboard or e-dashboard that can present data visually so that it is easily understood by readers.

The presentation of data in the form of an e-dashboard is more commonly used in the health sector both to monitor the condition of patients (Fischer et al. 2020; Goranson and Kang 2013; Martinez et al. 2018) and to monitor the performance of nursing services (Tan et al. 2013). Apart from health, electronic or visual dashboards are also used in a company to report supply chain operations in order to improve company performance (Busi \&

*name of corresponding author 
Strandhagen, 2004). E-dashboard in government supports the existence of an integrated instrument used for evaluation that can improve government performance (Marco, Mangano, and Zenezini 2015).

LPKA Class 1 Palembang has adopted the use of technology in the implementation of the philosophical school as developed by (Febrianty, Hadiwijaya, and Octafian 2019). Nevertheless, the term e-dashboard is still felt by both employees and the ranks of leaders in LPKA Class I Palembang. To provide an initial description of the e-dashboard system and equalize perceptions between researchers and LPKA Class 1 Palembang, an edashboard prototype was created which has basic functions for processing visits, complaints, submitting remissions and integration, as well as questionnaire analysis. (McLeod and Schell 2011) define a prototype as a tool that provides an idea for potential makers or users about how the system functions in its complete form.

Several studies have used the concept of prototyping in making the system and its application. Research by (Almarashdeh, Althunibat, and Elias 2014), built a prototype of a mobile portal for e-government services. The results of the research are m-Government with the functions of My SMS, M-services, and M-democracy which can be used to send automatic messages via SMS, transaction and payment services, and voting services. Another research was conducted by (Bastian and Yusuf 2017) who developed a prototype eco-village repeater network device using the green computing concept. The research was conducted to achieve the range of distances that can be passed by wireless signals in the Majalengka Wetan sub-district office, and after making the prototype, the maximum distance that can be passed by wireless signals is approximately $10 \mathrm{~m}$. The dashboard prototype was made by (Taufik and Nuqoba 2019) for the Brantas River water quality monitoring system. The prototype is used for real-time system monitoring and provides good evaluation results. (Lo'pez-Tavares et al. 2018) introduced a dashboard prototype for managing student activities and interactions in groups. The results of the study are in the form of data visualization that can provide ideas about how students can explain and explain student interactions in groups. The next dashboard prototype is used to analyze student interactions in using Twitter in the implementation of academic learning (Gruzd and Conroy 2018). The dashboard prototype in this study was used to see student interactions in accessing the same material and information in the learning class. A dashboard prototype for learning analysis was also developed by ( $\mathrm{Lu}$ et al. 2020) to support independent learning. The prototype development stage focuses on providing visualization of the learning process and behavior obtained from log data on the e-book system such as reading paths and e-book page slide access times.

This research will discuss the development of a service performance e-dashboard prototype in LPKA Class I Palembang. Services that are the focus of e-dashboard development include online registration of andikpas registration, complaints on LPKA services, services through online questionnaires, and requests for leave, remission, and assimilation.

\section{Electronic Dashboard}

\section{LITERATURE REVIEW}

In several studies (Mahendrawathi, Pranantha, and Utomo 2010; Yigitbasioglu and Velcu 2012), the term dashboard is often associated with a dashboard on a vehicle. The dashboard on the vehicle provides information in the form of the amount of fuel, vehicle speed, mileage, etc. which can be used to determine the status of the vehicle. In the field of informatics, an e-dashboard, or often referred to as a conceptual dashboard or visual dashboard, is a system that integrates all data processed according to a company's business processes and presents it in a form that is easily understood by system users.

(Apandi and Arshah 2016) define the dashboard as a single-screen interface with presentation graphics that display relevant information needed to achieve certain goals and is accompanied by an alert mechanism. The criteria for a dashboard based on (Apandi and Arshah 2016) $\square$ are:

1. Displays the information needed to achieve certain goals.

2. Presentation in graphic form.

3. The information displayed can be loaded in one screen.

4. Provide a warning mechanism if there is performance that does not meet the objectives.

\section{Prototype}

Prototyping begins with a collection of requirements that involves system developers and users to determine the objectives, functions, and operational requirements of the system (Ogedebe and Jacob 2017). The prototyping stages according to (Ogedebe and Jacob 2017) include:

1. Collection of needs.

2. Quick design process.

3. Building a prototype.

4. Evaluation and Improvement. 


\section{Unified Modeling Language}

UML is a standard language that is widely used in the industrial world to define requirements, make analysis and design, and describe architecture in object-oriented programming (Putra and Andriani 2019). Because UML is often interpreted as a language, in making models using UML, there are rules that must be followed (Pariyasto et al. 2018). (Pariyasto et al. 2018) defines UML as a system design model that has the advantage of making it easier for developers to use the object-oriented programming (OOP) paradigm in system development.

\section{METHOD}

Data collection was carried out by observation, interviews, and documentation to obtain the data needed in the e-dashboard development at both the design and construction stages of the software. The data used in this study were obtained from LPKA Class I Palembang. The data is in the form of data on prisoners and detainees, data, and procedures for submitting remissions, assimilation, leave and parole, data, and procedures for conducting visits, as well as data and procedures for evaluating performance.

The development of the e-dashboard prototype that will be carried out will follow the software development stages with the prototyping concept. The research stages were:

\section{Planning}

At this stage, researchers will communicate with users to define the types of e-dashboard users, identify the needs of each user, and agree on an outline of the system to be created.

\section{Design}

At this stage, the researcher performs prototype modeling using standard notations that are recognized by the system developer. This is done in order to achieve a common perception among developers on the functionality of the e-dashboard being developed as well as for future prototype improvements.

\section{Prototype Development}

At this stage, a prototype is made by coding using the appropriate programming language and techniques. The model created in the previous stage is translated into an e-dashboard prototype that has an appropriate way of working and functions.

\section{Prototype Evaluation}

At this stage, the prototype socialization is carried out in the form of a group discussion forum to introduce how the e-dashboard works and get feedback from users.

\section{Planning}

\section{RESULT}

The initial stage of prototype development begins with communicating between researchers and system users. At this stage, the identification of users in general, and their respective needs is obtained, as well as the data that will be processed or presented in the e-dashboard. The data is in the form of data on prisoners and detainees, data, and procedures for submitting remissions, assimilation, leave and parole, data, and procedures for conducting visits, as well as data and procedures for evaluating performance.

The results of the identification of needs that have been done can be described using a Use Case diagram. Use Case diagrams provide an overview of the expected functionality of a system and represent the interactions between users and the system. The Use Case component consists of actors who are system users (can be humans, software, or other hardware), and use cases which are behavior and what users can do on a system (Syafitri 2016). 


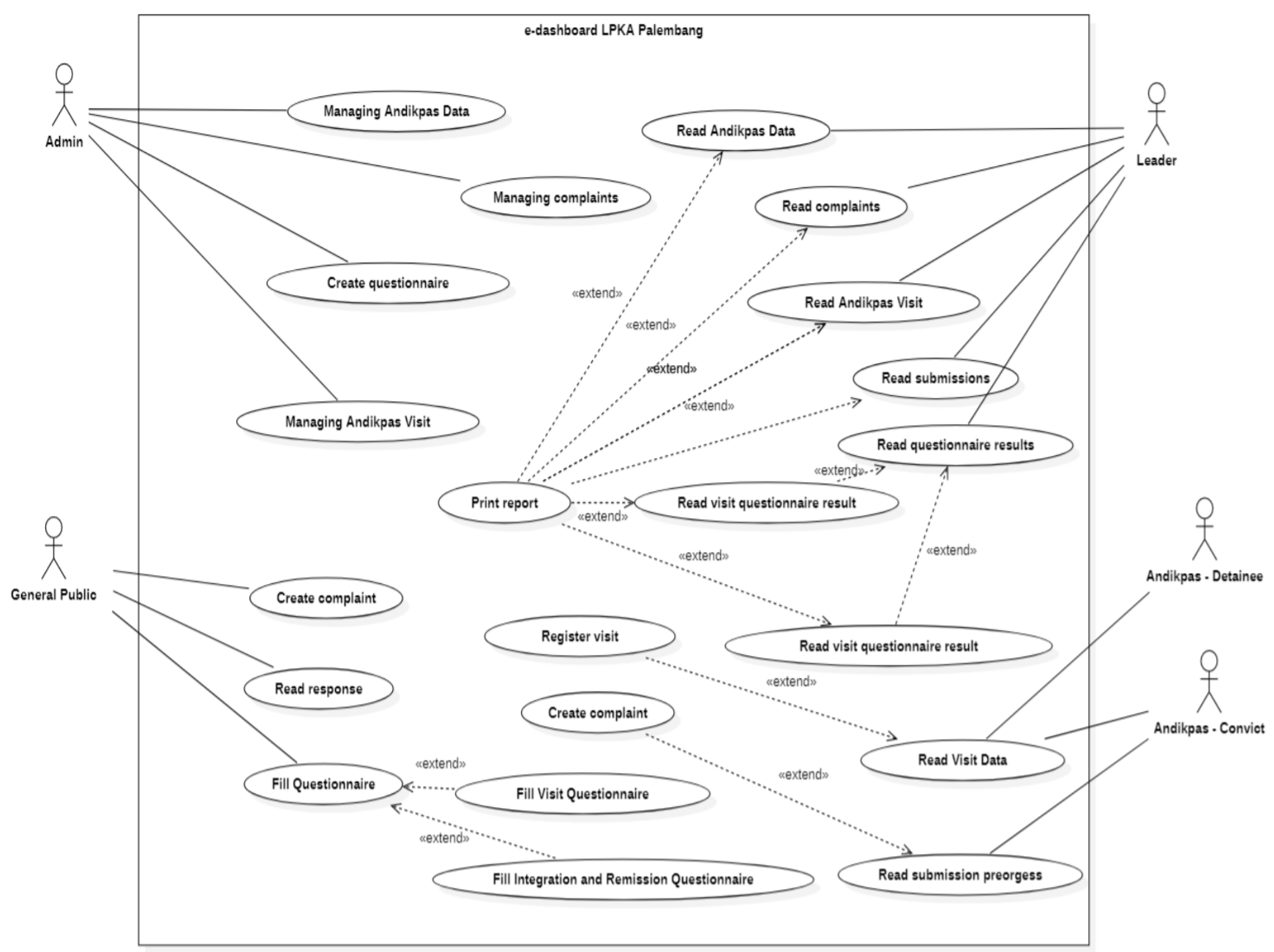

Fig. 1 Use Case Diagram of the LPKA Class I Palembang e-Dashboard System

Fig. 1 shows the Use Case diagram of the e-dashboard system at LPKA Class I Palembang. From the diagram, it can be seen that there are 5 types of e-dashboard system users, namely admin, leadership (Kalapas), Andikpas with prisoner status, Andikpas with prisoner status, and the general public. Further explanation regarding system users and the needs of each user for the e-dashboard system is summarized in Table 1.

Table 1

List of Users and Their Needs for the System

\begin{tabular}{|c|c|c|}
\hline No. & User & System Requirements \\
\hline 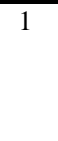 & Admin & $\begin{array}{l}\text { Manage (Add, Change, Delete, and View) all service data except questionnaire } \\
\text { results. In addition, admins can also manage: } \\
\text { 1. Andikpas data } \\
\text { 2. User data }\end{array}$ \\
\hline 2 & Inmate's family & $\begin{array}{l}\text { 1. See the record of visits that have been made. } \\
\text { 2. Propose remission, assimilation, } \mathrm{CMK}, \mathrm{CB}, \mathrm{CMB} \text {, and } \mathrm{PB} \text {. } \\
\text { 3. Viewing the records and status of remission, assimilation, } \mathrm{CMK}, \mathrm{CB}, \mathrm{CMB} \text {, } \\
\text { and } \mathrm{PB} \text { submissions. }\end{array}$ \\
\hline 3 & Prisoner's family & See the record of visits that have been made \\
\hline 4 & LPKA leaders & $\begin{array}{l}\text { 1. See all data managed by admin in tables and graphs. } \\
\text { 2. Print data in the form of reports. }\end{array}$ \\
\hline
\end{tabular}


In using the system, the first 4 users in Table 1 are required to log in first because they are related to the authority and need to access users' personal data. Meanwhile, for the general public, there is no need for user tracking. In checking the status of a complaint that has been given, users can access it by entering the same resident identity number used when entering the submission data.

A. Planning

After the planning process in the previous stage, the design stage is carried out by modeling the objects in the system and their relationship with each other statically using Class diagrams. Classes can be used to describe the state of a system through attributes or properties, and have services to manipulate the state through methods or functions (Isa and Hartawan 2017).
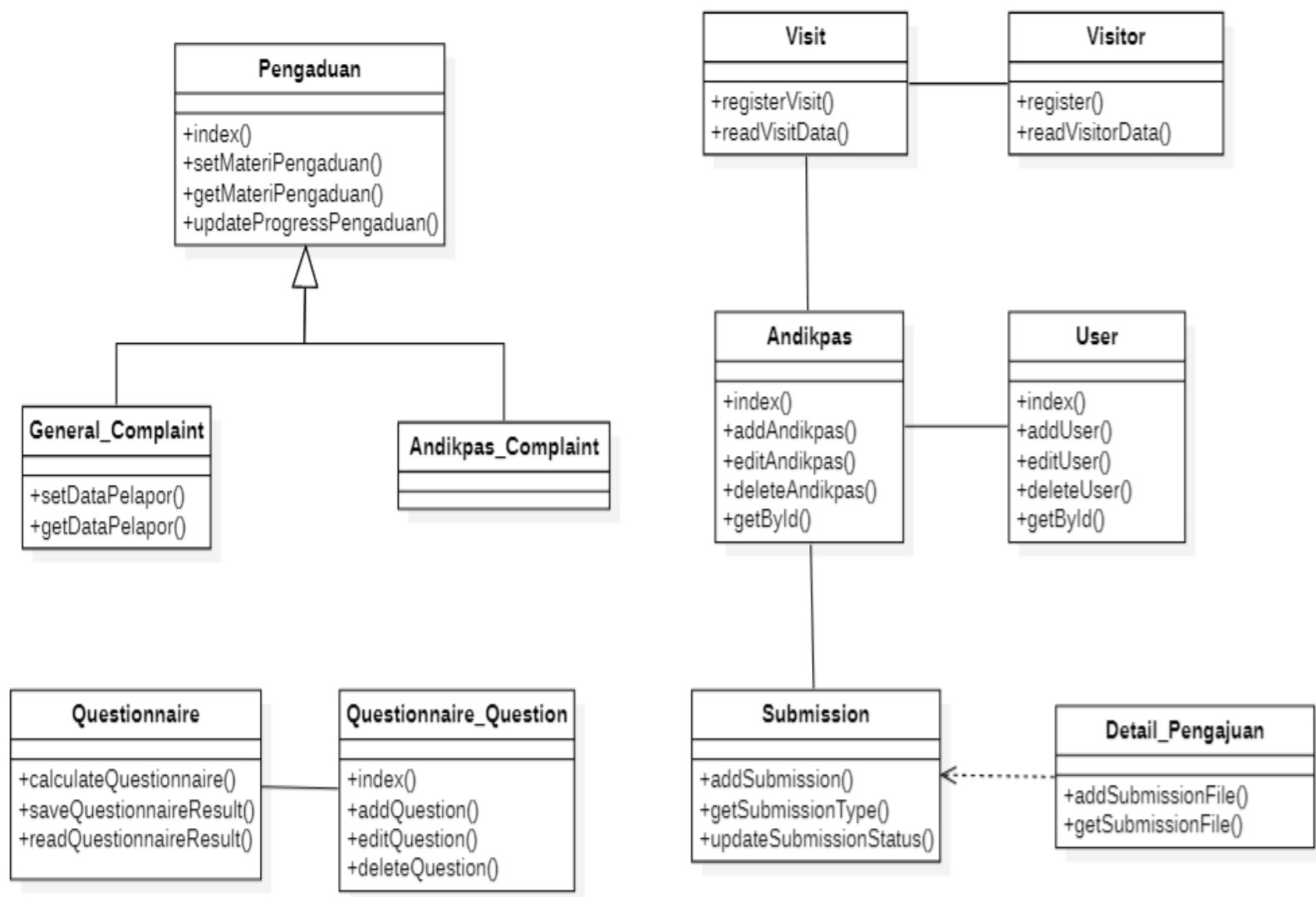

Fig. 2 Class diagram of the LPKA Class I Palembang e-Dashboard system

The next activity carried out is modeling a series of activities for each user to be able to achieve the functional requirements outlined in each use case in Fig. 1. Modeling is carried out using an Activity Diagram which is very similar to a flowchart because it models the workflow from one activity to another as well as other activities (Isa and Hartawan 2017). In the research, it is planned that the modules to be built are: prisoner data management, visit data management, regulatory data management (remission and integration), satisfaction survey (questionnaire), complaints, news management, coaching management, skills management, and gallery management. The need for based modules is provided by the client, meaning that these modules are mandatory in the e-dashboard system. 


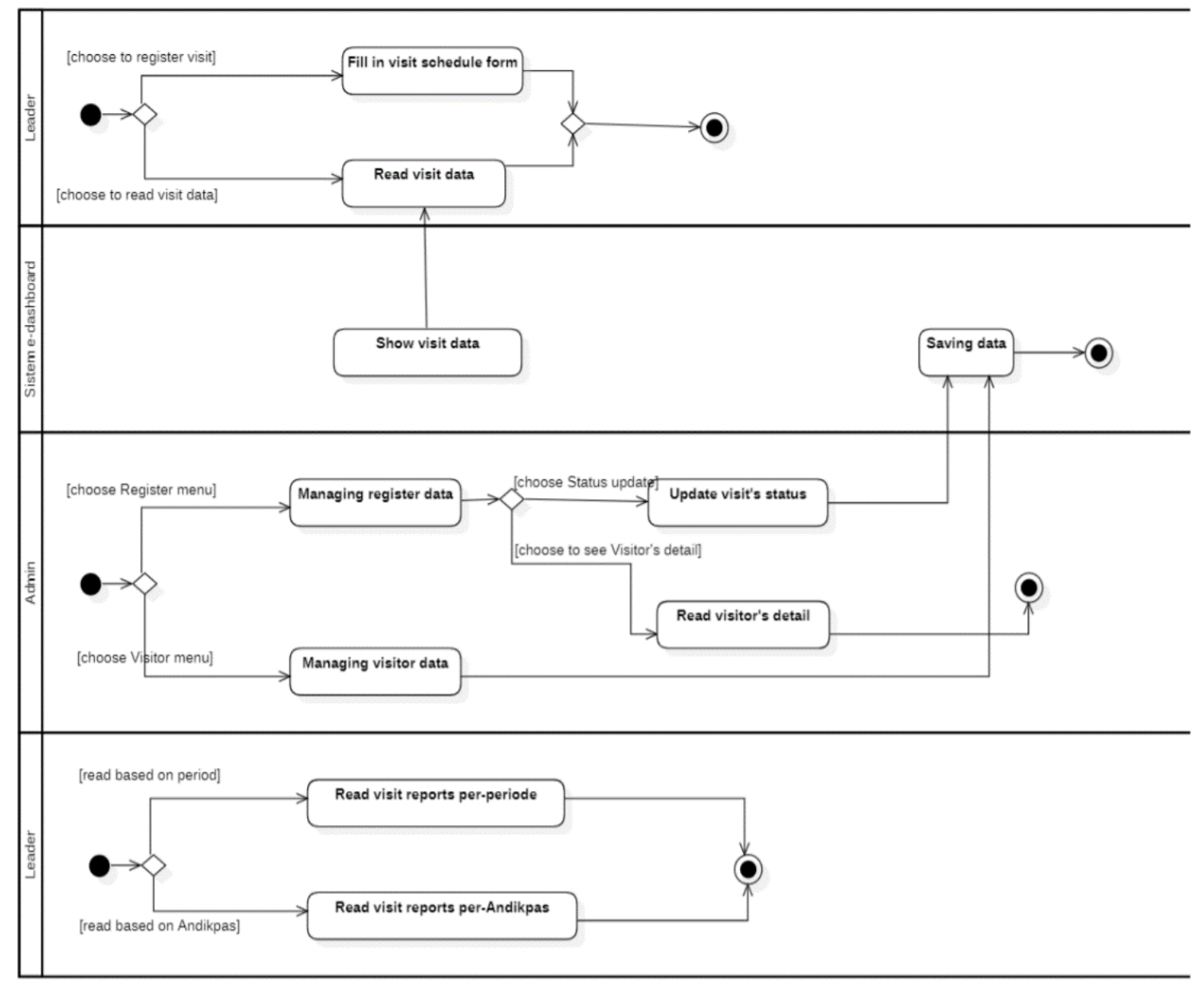

Fig. 3 Activity diagram of the e-Dashboard System for the Needs of the Visit Function

Figure 3 shows a diagram of user and system Activity in fulfilling functional requirements related to visits to Andikpas. Through the Andikpas account, families can register for visits by selecting the desired schedule. Families can also see data on visits that have been made to the relevant Andikpas.

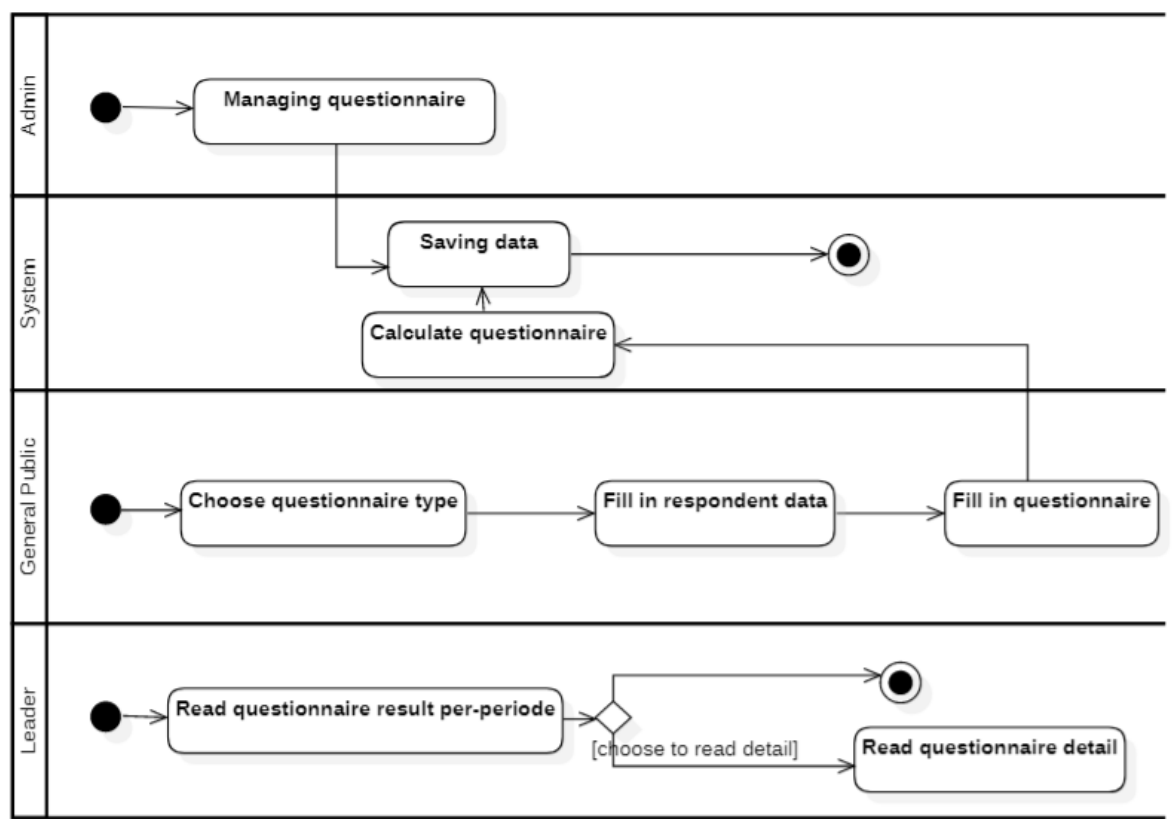

Fig. 4 Activity diagram of the e-Dashboard System for the Needs of the Questionnaire Function 
The series of activities on how system users can use the e-dashboard system for managing the questionnaire is shown in Fig. 4. The public can choose the type of questionnaire to be filled in, namely the Visit Questionnaire and the Integration and Remission Questionnaire. After that, the community is asked to enter their personal data and fill out a questionnaire. In managing the questionnaire, the admin only has the authority to manage the questionnaire questions, and the results of the questionnaire can only be seen by the leadership.

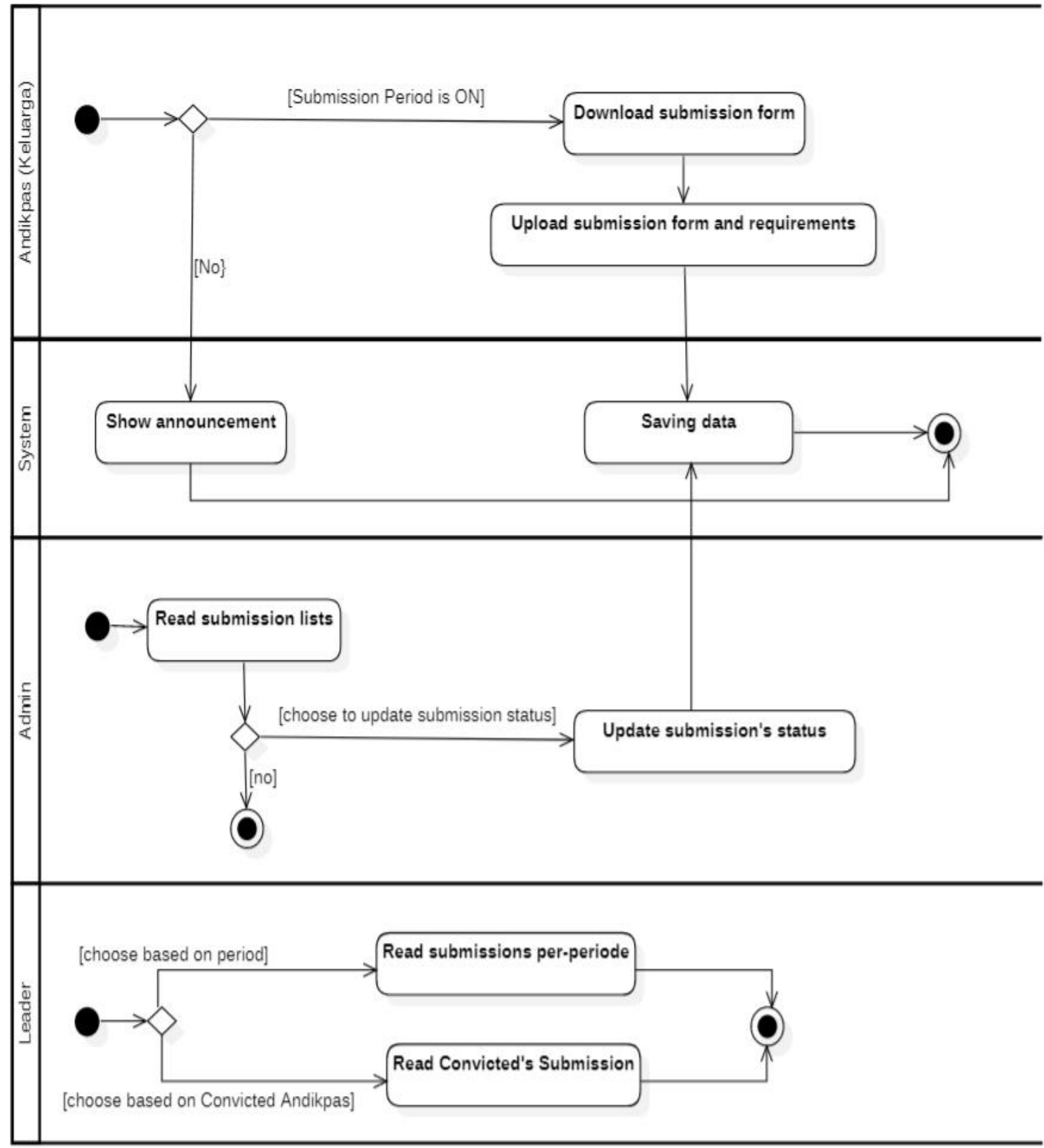

Fig. 5 Activity diagram of the e-Dashboard System for the Requirement of Submission Functions

A series of user activities in using the e-dashboard system to meet their functional needs in managing submission data is shown in Fig. 5. (Family of) Andikpas can submit submissions for CMK, CMB, CB, PB, remission, or assimilation by downloading the forms provided. Submissions are made by uploading the completed form by selecting the type of submission to be submitted. Both the leadership and (family of) Andikpas can see the record of submissions that have been submitted by Andikpas. 


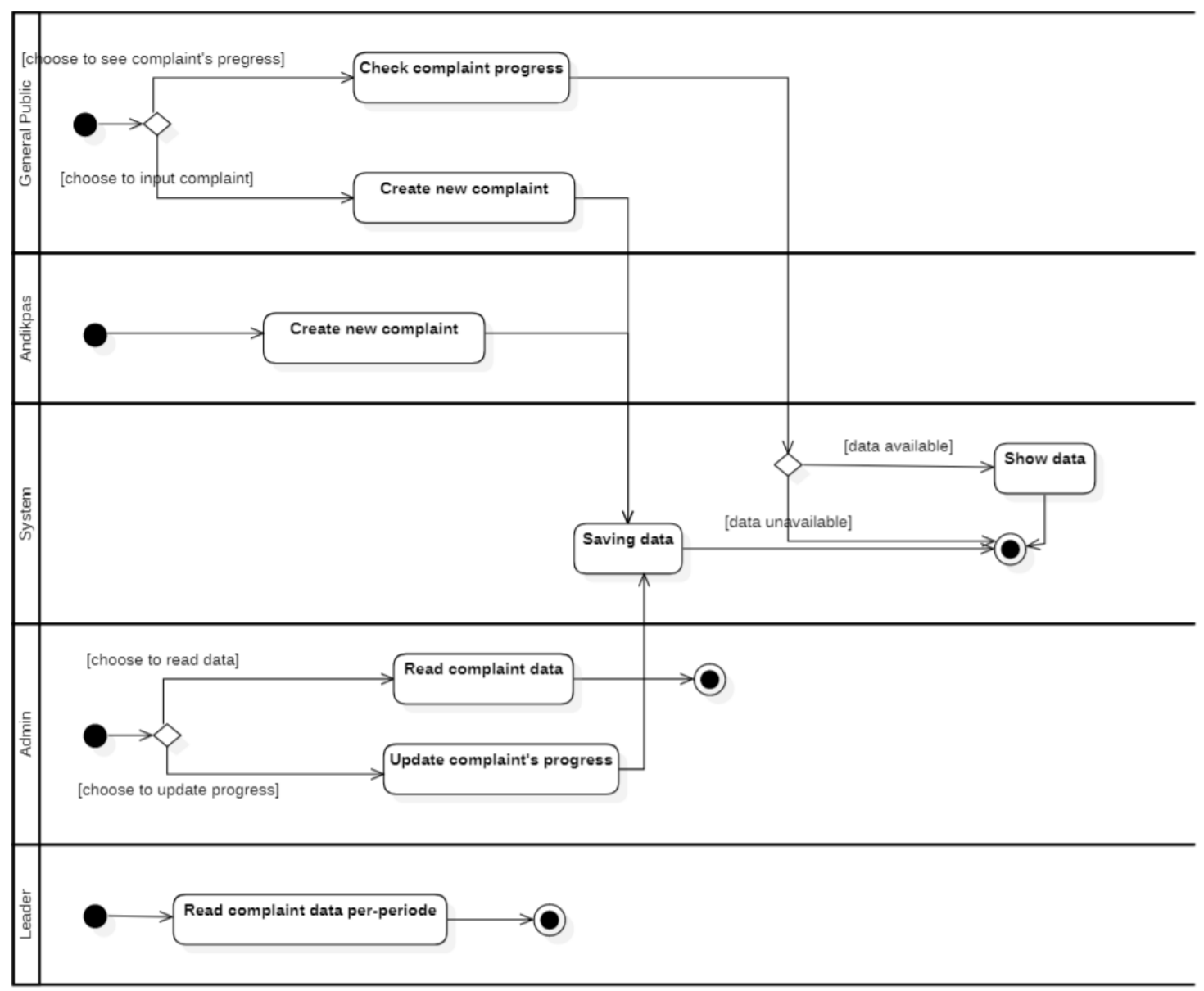

Fig. 6 Activity diagram of the e-Dashboard System for the Needs of the Complaints Function

Fig. 6 shows that the general public can make complaints about prison services in general. The general public can see the progress of complaints that have been submitted based on no. The identity it gives. Admin can add action data to complaint material that has been inputted by the public.

\section{B. Prototype Development}

At this stage, the e-dashboard prototype is built based on the models and designs made in the previous stages. The prototype to introduce the e-dashboard is built on a web basis and published on http://edashboardlpkapalembang.sumselprov.go.id/ so that it can be accessed by users.

Fig. 7 is the e-dashboard prototype web page for Andikpas (family) access rights. Both Andikpas with the types of prisoners and detainees can view data and register visits.

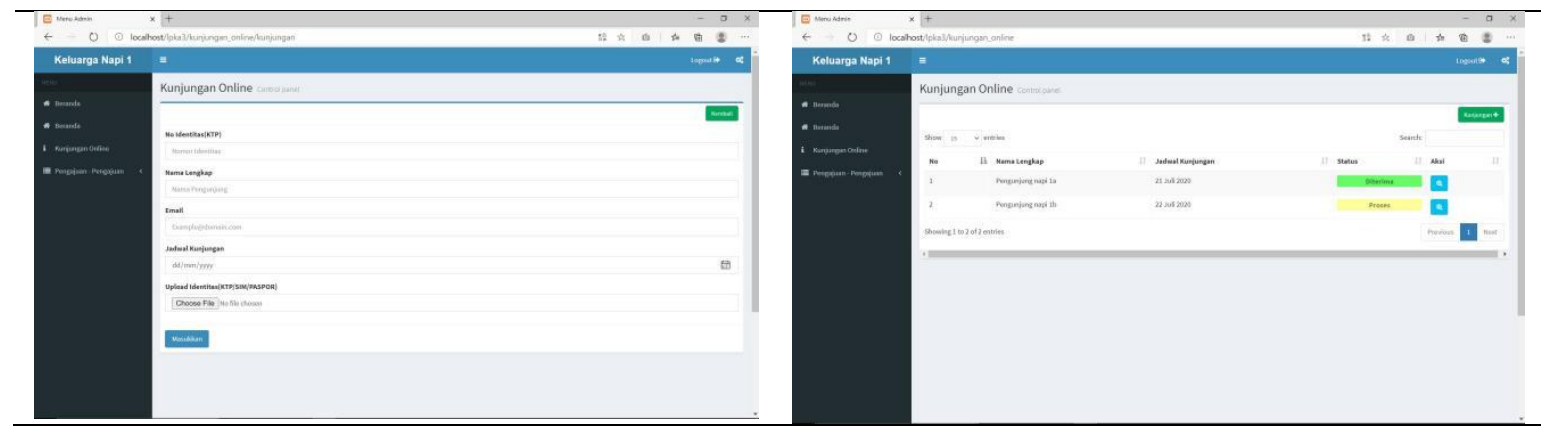

Fig. 7 Web Page Prototype of Visit Service Access for Andikpas (Family)

In Fig. 8, there is an e-dashboard prototype web page for the access rights of prisoners' families in accessing services for requesting leave, remission, and assimilation. Families can apply online and see the progress and history of submissions that have been made. 


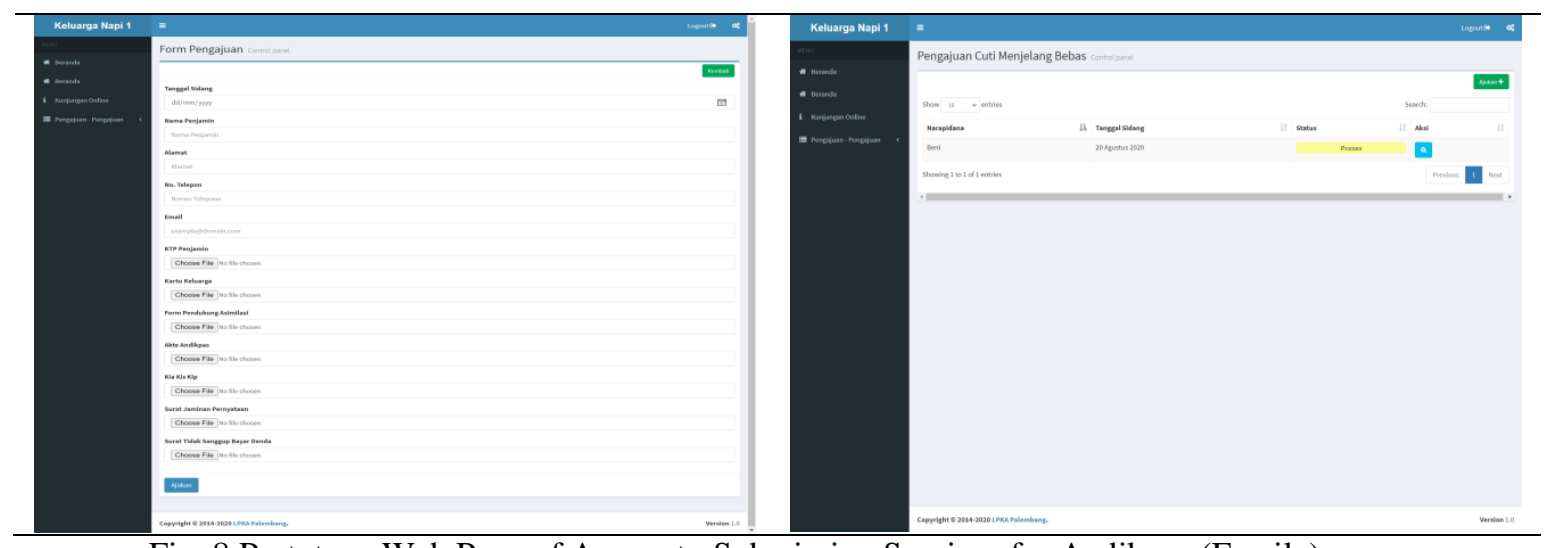

Fig. 8 Prototype Web Page of Access to Submission Services for Andikpas (Family)

The e-dashboard prototype web page for complaint services is shown in Fig. 9. The public can make complaints by filling in the compliant material in the system and checking the progress or status of complaints that have been given based on the identity number given.

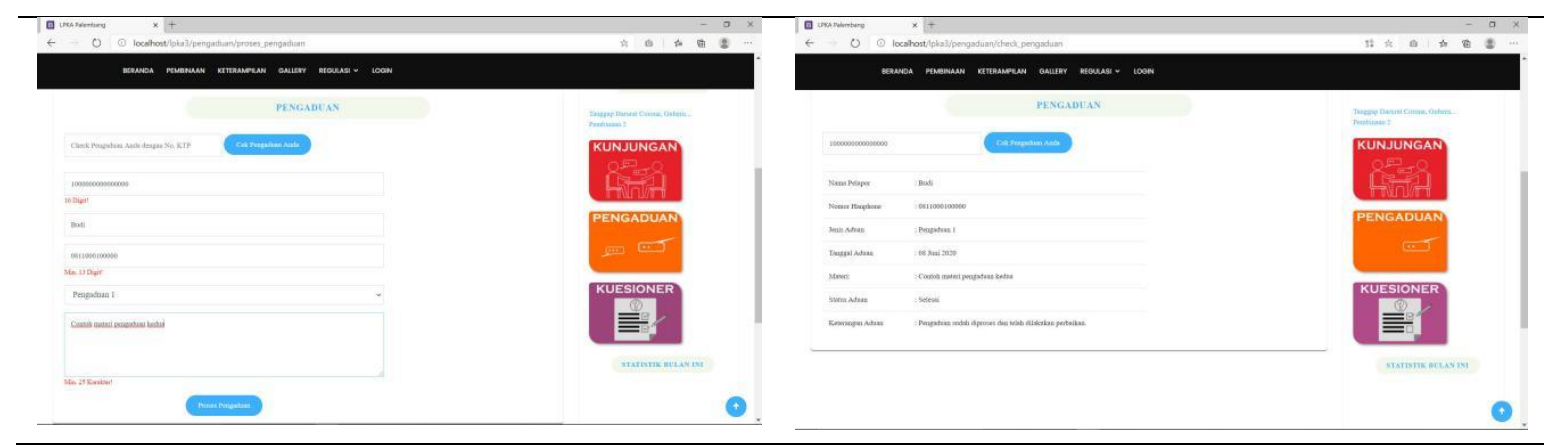

Fig. 9 Web Page Prototype of Complaint Service Access for the General Public

Questionnaire service

Fig. 10 shows the e-dashboard prototype web page for filling out the online questionnaire. Admins can add and modify questionnaire questions, as well as view existing questionnaire entries. The value of the entered questionnaire cannot be deleted or changed.

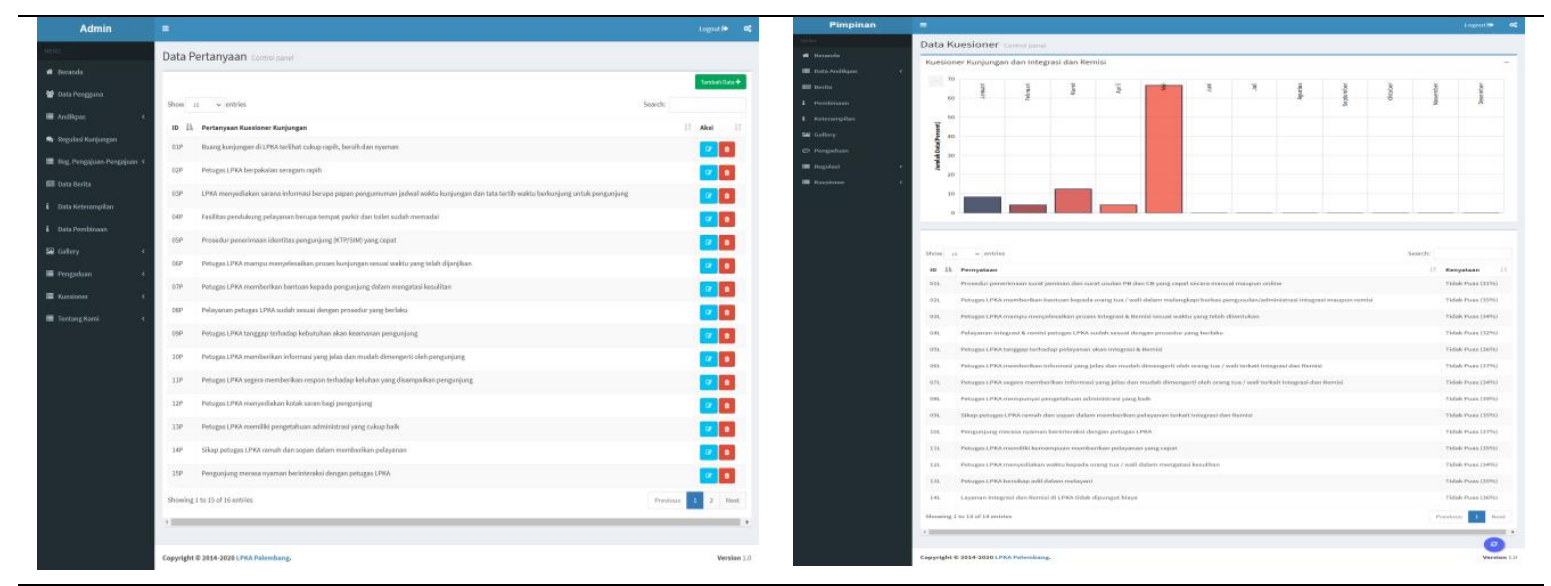

Fig. 10 Prototype Web Page Access to Questionnaire Services for Admins

C. Prototype Evaluation

At this stage, an evaluation of the prototype that has been built is carried out. Evaluation is carried out by holding a group discussion forum starting with the socialization of how to work and the use of the e-dashboard 
system. Direct feedback is obtained from users through suggestions and input on the functions and workings of the e-dashboard, as well as improvements to service procedures after the e-dashboard later. The results of user feedback are summarized in Table 2 .

Table 2

Results of User Feedback Prototype e-Dashboard

\begin{tabular}{|c|c|c|}
\hline No. & Module & System Requirements \\
\hline 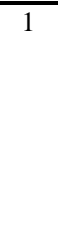 & User access & $\begin{array}{l}\text { 1. Admin access is divided in more detail according to the work field of each } \\
\text { service. } \\
\text { 2. The questionnaire service is administered by the field of improving the quality } \\
\text { of public services. } \\
\text { 3. Complaint services are administered by the field of strengthening supervision. } \\
\text { 4. Application services are administered by the coaching sector. } \\
\text { 5. Visiting services are administered by the registration and classification fields. }\end{array}$ \\
\hline 2 & Visit module & Visits can be made by the general public who knows Andikpas. \\
\hline 3 & Complaints module & $\begin{array}{l}\text { In addition to complaints given by the public regarding general complaints, } \\
\text { Andikpas can also provide complaints without recording the data record of the } \\
\text { complaint maker. }\end{array}$ \\
\hline 4 & Submission module & The submission process can only be done for a certain period. \\
\hline
\end{tabular}

\section{DISCUSSIONS}

The development of e-Dashboard using the prototyping method produces a simple system that simulates the basic functions possessed by e-Dashboard. The developed prototype has features that almost meet user needs because the system development is based on a quick analysis of the needs of future e-Dashboard users.

After the user has an overview of the e-Dashboard to be built, the user can communicate better in providing their needs according to the jobdesc they have and can provide input on the existing e-Dashboard prototype.

\section{CONCLUSION}

The e-dashboard prototype that was built could provide an overview of the group discussion forum participants consisting of employees and leaders of the Class 1 Palembang LPKA regarding the e-dashboard system to be developed. The e-dashboard prototype has functions and features that make it easy for the public to access services provided by LPKA in the form of visit registration services, complaint services, LPKA performance appraisal services through questionnaires and leave application services as well as remission and assimilation. The prototype had been tested by 144 out of 180 equals to $80 \%$ LPKA Class I Palembang employees. From the evaluation results obtained feedback that can be used as a basis for the development of the actual edashboard system.

\section{ACKNOWLEDGMENT}

Thanks to RISTEKDIKTI who has funded this Applied Research so that this research can be carried out properly and contribute to partners, namely LPKA Class I Palembang.

\section{REFERENCES}

Almarashdeh, I., A. Althunibat, and N. F. Elias. 2014. "Developing a Mobile Portal Prototype for E-Government Services." Journal of Applied Sciences 14(8): 791-797.

Apandi, and R.A. Arshah. 2016. "The Need of Dashboard in Social Research Network Sites for Researchers." International Journal of Software Engineering \& Computer Systems (IJSECS) 2: 120-32.

Bastian, A., and Budiman A Yusuf. 2017. "Implementasi Piranti Jaringan Repeater Eco Village Menggunakan Model Prototype Dan Konsep Green Computing." Jurnal Ilmiah Teknologi Informasi Terapan 3(3): 233240.

Febrianty, Febrianty, Hendra Hadiwijaya, and D Tri Octafian. 2019. Monograf E-School Filial LPKA Kelas 1 Palembang. Pekalongan, Indonesia: PT. Nasya Expanding Management.

Fischer, M. J. et al. 2020. "Development, Implementation and User Experience of the Veterans Health Administration (VHA) Dialysis Dashboard." BMC Nephrology 21(1).

Goranson, C, and J Kang. 2013. "Visual Dashboard and Heads-up Display of Patient Conditions (W81XWH-112-0025): Annual Report November." (3). 
Gruzd, A., and N. Conroy. 2018. "Designing a Learning Analytics Dashboard for Twitter-Facilitated Teaching." Proceedings of the 5th Annual ACM Conference on Learning at Scale, L at S 2018.

Isa, I. G. T., and G. P Hartawan. 2017. "Perancangan Aplikasi Koperasi Simpan Pinjam Berbasis Web (Studi Kasus Koperasi Mitra Setia).” Jurnal Ilmiah Ilmu Ekonomi 5(10): 139-151.

Lo'pez-Tavares, D. et al. 2018. "Dashboard to Evaluate Student Engagement with Interactive Simulations." Physics Education Research Conference Proceedings.

Lu, M., L. Chen, Y. Goda, and M Yamada. 2020. "Development of a Learning Dashboard Prototype Supporting Meta-Cognition for Students Development of a Learning Dashboard Prototype Supporting Meta-Cognition for Students." Companion Proceedings 10th International Conference on Learning Analytics \& Knowledge (LAK20).

Mahendrawathi, E., D. Pranantha, and J.D. Utomo. 2010. "Development of Dashboard for Hospital Logistics Management." In IEEE Conference on Open Systems (ICOS), , 86-90.

Marco, A. De, G. Mangano, and G Zenezini. 2015. "Digital Dashboards for Smart City Governance: A Case Project to Develop an Urban Safety Indicator Model." Journal of Computer and Communications 3(5): 144152.

Martinez, D. A. et al. 2018. "An Electronic Dashboard to Monitor Patient Flow at the Johns Hopkins Hospital: Communication of Key Performance Indicators Using the Donabedian Model." Journal of Medical Systems 42(8).

McLeod, Jr. R., and G. Schell. 2011. Sistem Informasi Managemen (Terjemahan). Jakarta, Indonesia: Salemba Empat.

Ogedebe, P. M., and B. P Jacob. 2017. "Software Prototyping: A Strategy to Use When User Lacks Data Processing Experience.” ARPN Journal of Systems and Softwar 2(6): 219-224.

Pariyasto, S. F. Y. C., U. Rizki, Z. Hisyam, and M Mashuri. 2018. "Analisis Kebutuhan Sistem Informasi Kepegawaian Menggunakan UML.” Seminar Nasional Sistem Informasi Dan Teknologi Informasi: 186190.

Putra, D. W. T., and R. Andriani. 2019. "Unified Modelling Language ( UML ) Dalam Perancangan Sistem Informasi Permohonan Pembayaran Restitusi SPPD.” Jurnal TEKNOIF 7(1).

Syafitri, Y. 2016. "Analisa Dan Perancangan Berbasis UML Pada Sistem Informasi Simpan Pinjam Koperasi Swamitra Bandar Lampung." Jurnal Sistem Informasi Dan Komputer 4(1): 22-31.

Tan, Y.-M. et al. 2013. "An Electronic Dashboard to Improve Nursing Care." Studies in Health Technology and Informatics 192(1-2): 190-194.

Taufik, and B. Nuqoba. 2019. "The Geographic Information System Dashboard Prototype of Brantas River, East Java." IOP Conference Series: Earth and Environmental Science 245(1).

Yigitbasioglu, O. M., and O. Velcu. 2012. "A Review of Dashboards in Performance Management: Implications for Design and Research." International Journal of Accounting Information Systems 13(1): 41-59. 